\title{
Introduction - contract and regulation: changing paradigms
}

\author{
Roger Brownsword, Rob A.J. van Gestel and \\ Hans-W. Micklitz*
}

\section{REGULATORY PRIVATE LAW}

The purpose of this Research Handbook is not to expound the law of contract or to debate nice doctrinal points that arise within that body of law. Rather, this Handbook is provoked by a number of questions arising from, first, public regulatory projects that seemingly rework and repurpose the (private) law of contract and, secondly, the extensive private regulation of both transactors and transactions. With regard to the latter, we need to understand more about the ways in which business communities organise and order their transactions in the shadow of the law of contract but also we need to pay critical attention to the use of contracting power by multinational corporations who can rival nation states in setting the terms of production and trade for their suppliers. With regard to the former, we need to reflect on the co-opting of private law in the service of public purposes and, in particular, the development of a regulatory mindset that views the law of contract as a tool to be shaped and applied for such purposes.

To the extent that commentaries on the law of contract ignore these questions, they neglect the actuality of transactional practices with which the law is intended to engage; they neglect the norms that actually guide contractors; they neglect the regulatory role played by some contractors; and they neglect the changing role that the law of contract plays in the regulatory environment. Such commentaries are like guidebooks that give detailed historic descriptions of city centres that are either no longer where we find the commercial and cultural life of the metropolis or that are in the process of being redeveloped for new futures.

* We would like to thank the European Research Council under the European Union's Seventh Framework Programme (FP/2007-2013) / ERC Grant Agreement n. [269722] for sponsoring the book project. 
In this opening set of introductory remarks we can indicate some of the elements that lead us towards the notion of 'regulatory private law' - a notion that captures, on the one hand, the phenomenon of private governance by contractors that has regulatory effects and, on the other, the co-opting and reshaping of private law (qua the law of contract) for public regulatory purposes.

\subsection{The Law of Contract: A Reality Check}

Recounting a conversation with his father-in-law, who was an experienced businessman, Stewart Macaulay recalls the former's surprise at hearing what the law schools taught in their Contracts courses. Evidently, the Contracts curriculum 'rested on a picture of the business world that was so distorted that it was silly'; ${ }^{1}$ for the doctrines of contract law that were taught in the law school bore little resemblance to the norms, customs and practices that actually guided business contracting. In practice, as Macaulay subsequently elaborated in his seminal article, 'Non-Contractual Relations in Business', ${ }^{2}$ business people rarely stood on their strict legal rights - for example, they would not usually enforce liquidated damages clauses or terminate for late performance - and they regarded suing a trading partner for breach of contract as a response of last resort. Moreover, the business people that Macaulay studied paid little attention to the law of contract in the way that they planned and put together their deals; and, far from finding it difficult to trust and transact with one another, or to compromise and cooperate, these people apparently got along just fine without orienting themselves to the law. ${ }^{3}$

What Macaulay's research revealed was not that business contractors dealt in a 'law-free' zone. Far from it, these contractors were guided by their own 'living law'4; but the rules and principles of that law were not necessarily those laid out by the law of contract. Or, in business

1 Stewart Macaulay, 'Crime and Custom in Business Society' (1995) 22 Journal of Law and Society 248, at 249.

2 (1963) 28 American Sociological Review 55.

3 Later research also reveals that, in other contexts too, law can play a very modest role in the settlement of disputes. See, e.g., Robert Ellickson, Order Without Law: How Neighbors Settle Disputes (Cambridge, MA: Harvard University Press, 1991) concerning disputes between neighbours in California in the case of damage caused by escaped cattle. Ellickson demonstrated that people largely govern themselves in settling these disputes by means of informal rules social norms - that develop without the aid of a state or other central coordinator.

4 Compare Eugen Ehrlich, Fundamental Principles of the Sociology of Law (New Brunswick: Transaction Publishers, 2001 [1913]). For a useful introductory 
contracting, as Roscoe Pound evocatively put it, we find a gap between the 'law in the books' and the 'law in action'.5 Although a handful of contract lawyers were stopped in their tracks by Macaulay's paper, for the most part contract scholarship continued as before, expounding and analysing the array of doctrines that seemingly were of little relevance to business contractors. What the law schools taught, and still teach, is the law of contract in the books not the practice of contractors and how that practice qualifies or simply ignores the parties' de jure rights and obligations. Ironically, then, while generations of students continue to be taught the law of contract on a business-as-usual basis, for commercial people themselves the basis of business is not the law of contract but the self-governing norms of the trading community.

Yet, unless Macaulay was seriously wrong, the regulation of transactions has, so to speak, a dark side (or, as legal pluralists might put it, another 'hemisphere' $)^{6}-$ and it is a side that remains relatively dark even half a century after Macaulay published his paper. ${ }^{7}$ Rather than shedding light on the law in action, academic contract law persists with its focus on the law in the books. In line with this narrow approach, the grand European project on the Draft Common Frame of Reference (DCFR), which has kept private lawyers busy for over a decade and which has led to an enormous amount of deepened knowledge on private law systems in Europe, has tended to exclude this empirical or 'evidence-based' dimension of contract law from the scope of the analysis, at least until recently. ${ }^{8}$ Thus, in so far as the Common Frame of Reference (CFR) offers itself as a 'toolbox', it enables some operations to be carried out in relation to the law in the books but it is unclear whether business people

overview, see Neil O. Littlefield, 'Eugen Ehrlich's Fundamental Principles of the Sociology of Law' (1967) 19 Maine Law Review 1.

5 Roscoe Pound, 'Law in Books and Law in Action' (1910) 44 American Law Review 12-36.

6 For a typology of the rules and norms to be found in the other hemisphere, see Marc Hertogh, 'What is Non-state Law? Mapping the Other Hemisphere of the Legal World' in Hanneke van Schooten and Jonathan Verschuuren (eds), International Governance and Law (Cheltenham: Edward Elgar Publishing, 2008) 11-30.

7 For a very helpful overview of the relevant literature, see Jonathan Morgan, Contract Law Minimalism (Cambridge: Cambridge University Press, 2013) ch 5.

${ }_{8}$ H.-W. Micklitz and F. Cafaggi (eds), The European Private Law after the Common Frame of Reference (Cheltenham: Edward Elgar Publishing, 2010). 
who self-regulate their transactions and marketplaces either need or will find any use for the tools. ${ }^{9}$

\subsection{The Law of Contract: Welcome to the Twenty-first Century}

So far as the law of contract is concerned, 'e-commerce' is simply another manifestation of 'offers' being made and then being 'accepted' or rejected. Whether deals are agreed on-line or deals are agreed off-line, a deal is a deal. However, regulators soon appreciated that there could be significant savings and new benefits if goods and services were traded on-line. In Europe any uncertainty about the legal enforceability of e-transactions was removed by Directive 2000/31/EC (the e-commerce Directive), which together with a number of contract- and consumerrelated Directives - some pre-dating e-commerce (such as Directive 93/13/EEC on unfair terms in consumer contracts) and others post-dating it (such as Directive 2011/83/EU on consumer rights) ${ }^{10}$ - comprise the regulatory framework for e-commerce. Inevitably, though, the relentless development of the Internet and associated digital technologies means that the law of contract is playing catch-up with the who, the what, and the how of on-line transactions.

Most recently, for example, following in the footsteps of eBay, we find a burgeoning 'share economy' with on-line networks - such as Uber, Airbnb, and Peerby - facilitating peer-to-peer consumer service provision, whether for taxis, parking space, or accommodation and so on. These on-line platform providers often organise their own rating systems (e.g. peer review by customers) and dispute resolution mechanisms (e.g. concerning complaints about fake reviews) but, at the same time, they try to stay out of the contractual relationship between the customer and the direct service provider (i.e. those individuals who rent out their house or room, offer taxi rides, or lend tools). Already these platforms cut out some traditional agents and intermediaries and, before too long, further technological developments (such as blockchain, distributed ledgers, and

9 Compare Norbert Reich, "'Reflexive Contract Governance in the EU" David Trubek's Contribution to a More Focused Approach to EU Contract Legislation' in Gráinne de Búrca, Claire Kilpatrick, and Joanne Scott (eds), Critical Legal Perspectives on Global Governance (Oxford: Hart, 2015) 273-294.

10 See, further, European Parliament, 'Contract Law and the Digital Single Market - Towards a New EU Online Consumer Sales Law?' (September 2015, PE 568.322). 
'smart contracts') might enable these networks to operate without even the involvement of the commercial platform provider intermediaries.

In practice, however, the operation and growth of these networks is provoking at least two kinds of concern. ${ }^{11}$ First, it is not clear how far the platform providers have a responsibility to ensure that the individual service providers are compliant with the health and safety standards that taxi companies, hotels, and so on have to meet. This suggests that there might need to be some public regulation of the sharing economy (as has already happened in some localities). Secondly, if the services provided to the consumer are not as agreed, then against whom is a claim to be made? From a traditional contract perspective, the appropriate defendant is the individual service provider; but if that individual does not have the funds to satisfy the claim, might there be a claim against the platform provider (with much deeper pockets)? Even if the individual service provider is a viable defendant, consumer claimants may judge that it is not worth going to the trouble of seeking a refund, especially where the service was provided abroad, or taking the matter further in the event that the on-line dispute resolution does not function properly. As in off-line consumer contracting, the costs of litigation usually outweigh the losses suffered by the individual claimant. That is why the consumer is often inclined to think: best to learn from the experience, possibly vote with one's feet, and trust to better luck next time. The fact of the matter is that traditional contract law and access to justice via the regular court system often do not function properly in situations of this kind because there is no coordination between the self-regulated arrangements made by the on-line platforms and the private law system in the off-line world.

The development of e-commerce, whether between business contractors, in B2C supply, or in peer-to-peer networks, is just one example of nineteenth-century contract laws needing to come to terms with the transactional realities of the twenty-first century. In practice, there is a multitude of situations in which traditional contract law is facing increasing problems, not only because of the complex network character of many relationships between contracting parties (in franchising, construction, multi-modal carriage of goods, financial services, and so on) but also because of the increasingly transnational dimension that more and more contractual relationships possess. Consequently, we have seen the rise of private regulation in many fields where traditional contract law

11 See, e.g., Larry A. DiMatteo, 'Regulation of Share Economy: A Consistently Changing Environment' in Reiner Schulze and Dirk Staudenmayer (eds), Digital Revolution: Challenges for Contract Law in Practice (Baden-Baden: Nomos, 2016) 89-109. 
falls short of providing a framework to facilitate social or economic relationships.

Consider, in this regard, the growing popularity of codes of conduct in $\mathrm{B} 2 \mathrm{~B}$ and $\mathrm{B} 2 \mathrm{C}$ relationships (concerning, for example, health and safety, environment, employment conditions, human rights, and the like). Notwithstanding that there is a lack of clarity about both the legal status of these codes and their enforceability, it appears that they serve useful purposes - at any rate, for those corporations that sign up to them otherwise there would not be so many of them. What is still underresearched, though, is how this form of private rule making relates to contract law practice. For example, where codes are imposed upon subcontractors by multinational companies via a contract, how voluntary is acceptance of these terms? Would the law of contract treat such provisions as enforceable? In the event of non-compliance, by whom might the terms be enforced - in particular, what is the position of third parties whose interests are impacted by the codes but who are not themselves signatories? Famously, in Doe v Wal-Mart Stores Inc, ${ }^{12}$ when employees (C) of foreign companies (B) who supplied Wal-Mart (A) claimed that the latter (A) were in breach of duty relative to a code of conduct (concerning labour standards) that Wal-Mart incorporated into its contracts with foreign suppliers (B), their (C's) action failed. Applying the law of contract, the claimants did not qualify as third-party beneficiaries of the provisions in Wal-Mart's supply contracts. ${ }^{13}$ If private governance in conjunction with the law of contract does not adequately protect the interests of employees and consumers, and so on, does the protective burden shift back to public regulation?

\subsection{Contract Law and Regulation}

In order to answer such questions we have to think anew about the relationship between contract law and regulation. This, it has to be conceded, might seem like an unpromising approach because contract law and regulation surely represent quite different paradigms. Typically, while regulation demands compliance, the law of contract merely facilitates; while regulation seeks to channel conduct, the law of contract is guiding only if adopted; while regulation aims to preserve some state of affairs or steer regulatees in a way that will lead to some desired new state of affairs, the law of contract (unless adopted) does not steer anyone

\footnotetext{
12572 F 3d 677 (9th Cir 2009).

13 See, e.g., Simon Baughen, Human Rights and Corporate Wrongs (Cheltenham: Edward Elgar Publishing, 2015) 165-166.
} 
and, even if adopted, it is not obvious that it steers towards some desired state of affairs; and, while the effectiveness of a particular regulatory intervention relative to its objectives can be measured, it is less clear how we might determine whether the law of contract is working.

Such doubts notwithstanding, we can start by thinking of contract law as being one element in the regulatory environment for transactions in a (competitive) market economy. The function of contract law is not to regulate competition as such but, in a modest way, to facilitate trade and commerce. In the name of public morals or the public interest, there are some kinds of transactions that contract law categorically will not enforce. Contract will also decline to enforce transactions where, although the agreements are perfectly permissible and unobjectionable, it is not thought appropriate to 'marketise' the arrangements or to 'contractualise' the relationship between the parties (hence the reluctance, for example, to treat family and social agreements as contractually binding and enforceable). We can also detect such a reluctance where the introduction of contract law might compromise relationships that are based on altruism or trust. For example, modern 'big biobanks' of the kind represented by UK Biobank or contemplated by the US Precision Medicine Initiative enter into quite complex agreements with their participants. ${ }^{14}$ The terms and conditions of these agreements, which are designed for long-term cooperation, cover some very important matters such as the privacy and confidentiality of the participants' data, the proprietary rights of the parties in relation to biosamples, the return of individual findings, the right to withdraw, recontacts with the participants, commercial access to the resource, and so on. On the face of it, this looks like a contract. However, if the point were put to the test, a court would think twice about holding that the parties intended to create legally enforceable contractual relations when participation was voluntary and unpaid, and when the culture was one of altruistic and trusting assistance with health research. On the other hand, the material transfer agreements that biobanks enter into with researchers are undoubtedly intended to be legally enforceable as contracts. Putting aside those cases where the adoption of the law of contract would change the complexion

14 See Roger Brownsword, 'Regulating Biobanks: Another Triple Bottom Line' in Giovanni Pascuzzi, Umberto Izzo, and Matteo Macilotti (eds), Comparative Issues in the Governance of Research Biobanks (Heidelberg: Springer, 2013) 41-62, and 'Big Biobanks: Three Major Governance Challenges and Some Mini-Constitutional Solutions' in Daniel Stretch and Marcel Mertz (eds), Ethics and Governance of Biomedical Research - Theory and Practice (Switzerland: Springer, 2016) 175-196. 
of the relationship in an unhelpful way, we are left with a variety of marketplace transactions (typically for the purchase of goods and services) where the essential regulatory function of contract law, such as it is, is to hold the parties to their deal - often amounting to little more than a mechanism for the collection of debts. However, enforcing transactions so that parties are held to their deal raises many detailed questions about who can hold whom to the deal, which terms of the deal can be enforced (and which cannot), how enforcement is to be translated into workable remedies, and how exceptional circumstances and excuses of one kind and another are to be treated. It is around fine-grained questions of this kind that different codes of contract law are written; and, truly, the devil of the law of contract is in the detail.

In the second half of the twentieth century many legal systems responded to the need to protect consumers against the non-negotiable small-print provisions of standard-form contracts, especially against exclusion clauses and limitations to the business supplier's liability. Initially, at any rate in the common law systems, judges manipulated classical doctrines in ways that gave consumers some protection but there were then systematic legislative interventions to control unfair terms and to support the reasonable expectations of consumers. For some commentators, consumer contract law thus became a distinct sub-section of the general law of contract; but, for others, the new protective measures in conjunction with the obligations now imposed on suppliers into the consumer marketplace were to be understood as instrumental in serving a specific and explicit public regulatory objective, namely the protection of consumers, the promotion of consumer trust and confidence, and support for the mass consumer marketplace.

In Europe, with the adoption of the Digital Single Market Strategy, ${ }^{15}$ and with the Commission proposing two new Directives - one on contracts for the supply of digital content, ${ }^{16}$ the other on on-line and distance sale of goods contracts ${ }^{17}$ - it seems that the regulation of the

15 European Commission, Communication from the Commission to the European Parliament, the Council, the European Economic and Social Committee and the Committee of the Regions, 'A Digital Single Market Strategy for Europe' COM(2015) 192 final (Brussels, 6.5.2015).

16 European Commission, Proposal for a Directive of the European Parliament and of the Council on certain aspects concerning contracts for the supply of digital content, $\operatorname{COM}(2015) 634$ final (Brussels, 9.12.2015).

17 European Commission, Proposal for a Directive of the European Parliament and of the Council on certain aspects concerning contracts for the online and other distance sales of goods, $\operatorname{COM}(2015) 635$ final (Brussels, 9.12.2015). 
consumer marketplace is about to enter a new phase. Reading between the lines of the proposals and of the recent history of which they are a part, we might detect two impulses for the Commission. One impulse is to salvage something from the considerable investment made in the CFR and the proposed (but now abandoned) Common European Sales Law (CESL). Imposing a common remedial regime, derived from the CFR and CESL, for on-line consumer sales - and, a fortiori for consumer sales, whether on-line or off-line - would be one way of justifying the investment. The other impulse is to prioritise the needs of prospective on-line suppliers lest they should decline to participate in the on-line market and, thereby, fail to contribute to economic growth in Europe. How far this might go remains to be seen. However, if the Commission's regulatory purposes (especially the desire for economic growth) so dictate, then we might find that the rules for on-line contracts come to dominate the rules for off-line transactions together with a prioritisation of the interests of small businesses over those of consumers (the latter being regarded as mere market functionaries).

Viewing contract law in this regulatory way, we can pose a number of questions, including whether the general law of contract is fit for purpose or whether it needs some adjustment to support the way in which business people understand the deals that they make; whether the bespoke body of consumer regulation is fit for purpose; and whether contractualising some relationships (where claims for breach of contract are not currently available) might be effective in serving some quite different regulatory purposes. Accordingly, we can think about what might need to be done if the law of contract is to play its intended role in the regulation of marketplace transactions and the protection of consumers; and we can also contemplate using the law of contract (possibly with some amendments) for quite different regulatory purposes (for example as a mechanism to hold corporations to their social, economic, and environmental responsibilities)..$^{18}$

Against this background, it is clear that nation states have had the official regulatory responsibility for marketplace transactions, whether as facilitators of commerce or as guardians of the consumer interest; but we also know, per Macaulay, that in practice there is a high level of unofficial self-regulation in commercial markets. Thus, we used to have general codifications of private law in almost every European Member State and, for a while, the European Commission tried to copy that

18 Compare F. Möslein and K. Riesenhuber, 'Contract Governance - A Research Agenda' (2009) 5 European Review of Contract Law 248, at 260. 
tradition to the EU level with the DCFR. However, it might very well be that the time of big codification projects lies behind us. Codification projects are often too inflexible and time consuming to meet the demands of today's private law practice, which is increasingly transnational, pluralistic, and value laden. This at least partly explains why private regulation has grown in popularity. Codes of conduct, covenants, private standards, certification schemes, and so on have the advantage of being form free, faster to establish, more flexible, and hence more adaptable to changing circumstances.

Simultaneously, empirical studies have shown that the basic assumptions underlying the law of contract such as:

(a) parties know what they want (they understand their preferences), (b) they have relatively clear expectations about what their contracting counterparts want (they have a good sense of their counterparts' preferences), (c) they understand when they have entered into a contract, (d) they generally feel bound to perform as obligated by lawful contracts into which they knowingly entered, and (e) if they breach, they know they are breaching

no longer accord with the modern reality of how contracts and contract law are perceived. ${ }^{19}$ Apart from that, contract law has become less value neutral and more policy oriented and, particularly in relation to those contractors who are treated as vulnerable, paternalistic. ${ }^{20}$

In this context, one of the main reasons to write this Handbook was to see to what extent, on the one hand, (State-initiated) contract law and, on the other, self-regulation (by commercial contractors and merchants) are growing towards one another, thereby changing the paradigms on which both public regulation and private contract law rest. Are there new forms of regulatory private law arising and, if so, what does this mean for the coherence of private law and the theoretical foundations on which it rests? Hans Micklitz has coined the term 'regulatory private law', ${ }^{21}$ which not so long ago would have been perceived as an oxymoron; something similar to 'ordering someone to be spontaneous', which is of course impossible. Today, the idea of regulatory private law is no longer viewed as absurd. However, this certainly does not mean there is

19 Z. Eigen, 'Empirical Studies of Contract' (2012) 8 Annual Review of Law and Social Science 292-293.

20 P. Cserne, Freedom of Contract and Paternalism (New York: Palgrave Macmillan, 2012).

21 'The Visible Hand of European Private Law' in P. Eckhout and T. Tridimas (eds), Yearbook of European Law 2009, volume 28 (Oxford: Oxford University Press, 2010) 3-60. 
consensus on the change of paradigms in private law. This Handbook aims to advance our understanding of the place and purpose of, as well as the prospects for, contract law in the regulatory landscape by studying three phenomena in the field of private law where contract and regulation are meeting, namely 'codes of conduct', 'networks', and 'compliance'. By exploring these areas, we want to contribute to the theoretical underpinning of (European) regulatory private law as well as offering a compass for practitioners who are working in this field.

\section{THE IDEA OF A 'REGULATORY SPACE'}

The general idea of this Research Handbook is to shed some light on the dark side of contracting communities and contracts. First, we need to understand more about the regulatory role played by these contractors and the capacity of contracts to serve as agreements with regulatory effects. In a certain way, one could argue that contract is the oldest form of private regulation because it enables people to regulate their own lives and benefit from cooperation in a way that satisfies mutual expectations and provides legal certainty. However, the context within which contracts take shape has changed drastically, as we mentioned above. Therefore, we will focus on exploring the 'regulatory space' in which agreements are planned, deals are done, and obligations need to be fulfilled. From a legislative perspective, this space is roughly equivalent to the scope of the particular regulatory measure - whether the measure is aimed at distance selling to consumers, providing cross-border services, or large construction or shipping projects, and so on.

Secondly, because it is the self-governing practice of contractors that needs to be illuminated, we will adopt a 'bottom-up' approach that views this transactional space through the eyes of contractors. From the perspective of the transacting parties, the regulatory space might look very different: the parties might not be aware of the regulatory intentions of one or more of the contractors that go beyond the pure self-interest of the parties or they might misunderstand its meaning, or they might simply ignore it because there are competing norms in play. Moreover, bearing in on the regulatory space, we might find there are modes of governance that do not fit nicely into traditional contract theory because of obscurity regarding the binding nature of the relevant agreements, their public/private character, their national versus transnational orientation and so forth. Alternative modes of governance (not least including the use 
of technological design and management) ${ }^{22}$ are mushrooming and increasingly collide with traditional contract law because private law (or lawyers?) can have difficulties with embracing these new forms.

In our view, the latter has to do not only with the hybridity of new governance mechanisms, but also with the fact that in traditional private law the (national) legislature and the judiciary function as the gatekeepers of the legal system. Whatever is not recognised either by the legislature or the judiciary does not seem to count as law. ${ }^{23}$ We have seen magnificent struggles by both legislatures and judges to deal with the complexities of hybrid private regulatory mechanisms in this respect. An interesting case in point is the practice wherein legislatures - whether the national legislature or the EU legislature - refer to private standards. What does that signify for the legal status of these standards? A few years ago the Dutch Supreme Court dealt with such a case in which it needed to decide whether copyright law was applicable to private standards to which public laws and regulations refer. The Dutch Copyright Act determines in Article 11 that 'No copyright subsists in laws, decrees or ordinances issued by public authorities, or in judicial or administrative decisions.' This raised the question: do private standards change colour and turn into public law as the legislature refers to them? The Supreme Court answered this question in the negative, mainly because most public laws contain an 'equivalence clause', leaving the norm addressees an option to comply by following the norms set in the private standards or otherwise proving that they comply with the underlying legislative provisions. This decision was criticised because in reality the alternative route was mostly unrealistic (e.g. far more expensive than complying with the private standards). Moreover, since the result of the alternative compliance test should be similar to the outcome of the private standards, this still made the standards the point of reference.

There is a view that the decision by the Supreme Court was determined by economic considerations since the most likely consequence of lifting the copyright on standards in case of a reference in public laws or regulations would probably mean that it would no longer be profitable for

22 See, e.g., Roger Brownsword, 'In the Year 2061: From Law to Technological Management' (2015) 7 Law, Innovation and Technology 1-51 and 'Field, Frame and Focus: Methodological Issues in the New Legal World' in Rob van Gestel, Hans-W. Micklitz, and Ed Rubin (eds), Rethinking Legal Scholarship (Cambridge: Cambridge University Press, 2016) 112-172.

23 See J.B.M. Vranken, Exploring the Jurist's Frame of Mind (The Hague: Kluwer Law International, 2006) 78-79. 
private standard organisations to invest in the standard-setting process without the revenues from copyright leaving the legislature completely empty handed. This example clearly shows that courts and legislatures often have difficulties in determining when and why private regulations should (not) be given force of law. Describing this process, Vranken says:

There seems to be a socialising of law that is directly related to an increasing reliance of society on regulation, to an extent never seen before. Law loses part of its autonomy, because it is forced to accept private regulation. On the other hand, society loses part of its autonomy, because its private regulation will have to conform to (minimum) legal standards. I can put it in another way. Almost a century ago, Eugen Ehrlich said that the emphasis on the mutability of law is not on the legislator, adjudication, or literature, but on society itself. The (predecessors of the) American legal realists argued the same point. This means that, although dealing with civil law remains trapped in the framework of legislation and adjudication, the framework itself can never completely overtake the intrinsic mutability of law. In the end it is social reality that is ahead of current law. This is another way of saying that argument in civil law will always be jumping with feet of clay. ${ }^{24}$

By framing our inquiries in terms of the 'regulatory space' (or the 'regulatory environment') in which the law of contract stakes its claim to oil the wheels of commerce, ${ }^{25}$ to inform and protect consumers, and to 'make markets' and facilitate transactions, we are allowing for a broad range of normative signals - not only those that are directly embedded in, or indirectly incorporated into, the doctrines of contract law recognised by legislatures or courts. It follows that the norms, understandings, and expectations that are actually foregrounded in business practice, consumer behaviour, and (other) stakeholder perceptions are at least as much a part of our inquiry as the official legal norms that might be neglected by transactors and left in the background.

By adopting a 'bottom-up' rather than a 'top-down' approach, we can shed light not only on the way in which contractors relate to the law of contract, but also on their activities as self-regulating groups. As common law jurisprudence highlights, there are uncomfortable decisions to be made when the expectations generated by 'bottom-up' governance meet the 'top-down' rules of contract law. As we have seen, something similar applies to civil law practice where private regulations and hybrid forms of governance do not nicely fit into the rules of recognition set by private

24 Ibid, p. 81

25 Lord Goff, 'Commercial Contracts and the Commercial Court' [1984] LMCLQ 382, at 391. 
law codifications. The question, of course, is whether priority should be afforded to the bottom-up or top-down approach; or whether some sort of synthesis should be developed? ${ }^{26}$ In case of the latter, how should we separate the wheat from the chaff when it comes to new modes of private law situated somewhere in between traditional contract law and public regulation? When do we acknowledge codes, covenants, standards, and so on, as legally binding?

We anticipate that our methodology may be deeply disruptive of some familiar classical distinctions. For example, once we take seriously the full set of regulatory signals that are operative in a particular transactional context, we immediately disrupt the distinction between what is law and what is not, as well as between what is binding and what is not. ${ }^{27}$ Moreover, once we examine who does what within the regulatory space, we will find that there is no sharp line between the private and the public, the individual and the collective, the regulators and the regulatees, and so on. We accept this as a fact of life and will start by considering what the function of, in this case, codes of conducts, networks and private compliance mechanisms is because, as Lon Fuller has taught us, one cannot tell what the law is, without telling what it is for. ${ }^{28}$ This will not be enough though. We will also have to study where such hybrids cause tensions with existing contract law and whether we can distinguish general patterns and accepted practices that could tell us more about how we might give these new hybrids a proper place in the no-man's-land between contract and regulation.

26 Compare Stewart Macaulay, 'The Real and the Paper Deal: Empirical Pictures of Relationships, Complexity and the Urge for Transparent Simple Rules' (2003) 66 MLR 44. For a flavour of the issues, compare Morgan (n 7) and Catherine Mitchell, Contract Law and Contract Practice (Oxford: Hart, 2013).

27 See, further, Brownsword (n 22); 'Technological Management and the Rule of Law' (2016) 8 Law, Innovation and Technology 100-140; and 'Law as a Moral Judgment, the Domain of Jurisprudence, and Technological Management' in Patrick Capps and Shaun D. Pattinson (eds), Ethical Rationalism and the Law (Oxford: Hart, 2016).

28 Lon L. Fuller, 'Positivism and Fidelity to Law - A Reply to Professor Hart' (1958) 71 Harvard Law Review 630-672 and The Morality of Law (New Haven, CT: Yale University Press, 1964). 


\section{THREE MAJOR THEMES: CODES, NETWORKS AND COMPLIANCE}

So much for the general approach, but where do we start? Although the dark side of contract might remain dark, we believe that we can make some educated guesses at what will be salient features of the future role of hybrid governance mechanisms with both regulatory and contractual characteristics within the regulatory space. Accordingly, as an initial step, we propose to focus on the following three phenomena: (1) codes of conduct; (2) network governance; and (3) compliance.

As we explore these new modes of governance, our focus is on the implications for contract law, particularly in relation to the methodology of law making and the interaction between contractual self-governance (the bottom-up perspective) and governmental regulation (the top-down perspective). With regard to the governmental perspective, we will pay special attention to the leeway that courts and legislatures give or refuse to give to codes of conduct, networks and private compliance strategies that go beyond traditional unilateral and bilateral contractual agreements. Where do these new modes of governance conflict with existing paradigms in contract law and which routes may have been chosen so far to bypass these paradigms?

\subsection{Codes of Conduct}

There is a large body of literature about sources of law beyond those produced by the legislative bodies of nation states. ${ }^{29}$ In this 'pluralist' body of work, lawmakers are found not only beyond the nation state but also at sub-national level. By and large, however, this literature of governance through codes of conduct (also known as charters, covenants, and concordats) has not had much impact on either the direction or the focus of the scholarship of contract law. ${ }^{30}$

29 See, e.g., Douglas Lewis (ed), Global Governance and the Quest for Justice Volume 1: International and Regional Organisations (Oxford: Hart, 2006); Jan Klabbers, Anne Peters, and Geir Ulfstein, The Constitutionalization of International Law (Oxford: Oxford University Press, 2009); and Andrew Halpin and Volker Roeben (eds), Theorising the Global Legal Order (Oxford: Hart, 2009).

30 For a notable exception, see Jan M. Smits, 'Plurality of Sources in European Private Law, or: How to Live With Legal Diversity?' in Roger Brownsword, Hans-W. Micklitz, Leone Niglia, and Stephen Weatherill (eds), The Foundations of European Private Law (Oxford: Hart, 2011) 323. 
Codes of conduct can be found in B2B and B2C relationships. Think, for example, of codes that regulate the provision of SMS services to consumers, codes regarding the (pre-)contractual relation between energy suppliers and consumers and direct selling, and codes of conduct between a multinational enterprise (MNE) and subcontractors in the sphere of anti-corruption management and corporate social responsibility initiatives. Reflecting on such examples, Cafaggi speaks of 'new regulatory models coordinating public and private regulators'. ${ }^{31}$ According to him, codes of conduct may help to address market failures but this is only one of the many functions which they fulfil in practice. ${ }^{32}$

Taking into account the popularity of self-regulation in (European) private law, one would expect different legal actors in private law, such as the legislature, the judiciary, and the scholarly legal community, to pay close attention to the legal framework within which different types of codes of conduct need to function. Surprisingly enough, however, there are only a few sources providing some clarity as to the legal status, the publicity, possibilities for judicial review, and legitimacy of codes of conduct from a private law perspective. ${ }^{33}$ To some extent, this might explain why a legal framework for the use of codes of conduct is lacking at the moment both at the European and the Member State level. As a result, scholars often compare codes of conduct with governmental regulation but one may doubt whether this approach is convincing since these codes are often meant to serve as an alternative to state-made rules and regulations. ${ }^{34}$ It is highly unlikely that codes of conduct can be successful in this respect as long as we try to impose similar procedural requirements with regard to legitimacy, transparency, enforceability and

31 F. Cafaggi, 'Rethinking Private Regulation in the European Regulatory Space' in F. Cafaggi (ed), Reframing Self-Regulation in European Private Law (Alphen aan den Rijn: Kluwer Law International, 2006) 3-75.

32 See for an empirical inquiry with regard to the use of codes of conduct in (European) private law: M. Menting, The Role of Codes of Conduct in Regulatory Private Law ( $\mathrm{PhD}$ dissertation: forthcoming).

33 Most of the literature is written from a political science, public administration, and regulation and governance perspective. Notable exceptions are Stefan Grundmann, Florian Möslein, and Karl Riesenhuber (eds), Contract Governance: Dimensions in Law and Interdisciplinary Research (Oxford: Oxford University Press, 2015) and Gralf-Peter Calliess and Peer Zumbansen, Rough Consensus and Running Code: A Theory of Transnational Private Law (Oxford: Hart, 2010).

34 C. Scott, 'Regulating Private Legislation' in F. Cafaggi and H. Muir-Watt (eds), Making European Private Law: Governance Design (Cheltenham: Edward Elgar Publishing, 2008) 263. 
so on, which are treated as essential with regard to public laws and regulation on private codes.

The question of whether we need tailor-made legal warranties for the use of codes of conduct can only be answered after we have studied the legal problems accompanying these codes and after we have studied to what extent existing contract law is able to deal with these problems. Moreover, one needs to realise that codifying certain 'rules of the game' either via legislation or via case law with regard to the use of codes of conduct might look sensible at first sight. However, if one raises the threshold for the use of codes of conduct in the realm of private law, one runs the risk that they lose their attractiveness as light-touch alternatives to existing rules of contract law, which might also affect their selfregulatory capacity. In other words, there could be a trade-off between legal warranties and functionality. Accordingly, we need to keep an open eye for the possibility that codes of conduct in the field of private law might function better in the shadow of the law, as long as we succeed in keeping the possible negative (side-) effects of the use and possible abuse of codes under control. The more intriguing question could therefore very well be: which private law doctrines or theories could be used to circumvent or remedy the flaws of codes of conduct?

\subsection{Network Governance}

In recent years, there has been a surge of interest in contractual 'networks'. ${ }^{35}$ There has also been a renewed appreciation of the significance of Ian Macneil's work on relational contracts. ${ }^{36}$ Much of the debate has been triggered through systems theory and by the ground-breaking

35 Notably, see Marc Amstutz and Gunther Teubner (eds), Networks: Legal Issues of Multilateral Cooperation (Oxford: Hart, 2009); Gunther Teubner, Networks as Connected Contracts (Oxford: Hart, 2011) (translated by Michelle Everson, and with an exceptionally helpful introduction by Hugh Collins); Fabrizio Cafaggi (ed), Contractual Networks, Inter-Firm Cooperation and Economic Growth (Cheltenham: Edward Elgar Publishing, 2011); and Stefan Grundmann, Fabrizio Cafaggi, and Giuseppe Vettori (eds), The Organizational Contract: From Exchange to Long-Term Network Cooperation in European Contract Law (Aldershot: Ashgate, 2013).

36 Seminally, see Ian R. Macneil, The New Social Contract (New Haven, CT: Yale University Press, 1980); and, for re-evaluation, see David Campbell, Linda Mulcahy and Sally Wheeler (eds), Changing Concepts of Contract (Basingstoke: Palgrave Macmillan, 2013). 
analysis of franchise contracts ${ }^{37}$ as a form of relational contracts and later on through the financial crisis where the failure of contract law has been identified as one of the key elements in triggering the so-called subprime crisis. In the field of financial services a whole variety of networks exists which challenges the understanding of privity of contract and which, in the aftermath of the Lehman Brothers' bankruptcy, raised all sorts of difficult doctrinal and theoretical questions about third-party liability, such as the responsibilities of accountants and credit-rating agencies in warning banks, insurance companies, pension funds, and so on about the risks of certain investments. An interesting contrast with codes of conduct is clearly that 'light-touch' regulation with regard to the relationships within and between financial networks, which was very popular before the credit crunch, has lost much of its appeal since then.

Clearly, within the regulatory space that immediately opens up when we broaden the perspective beyond bilateral contract to networks of relations where we find parties transacting, there are various articulations of network relationships. In principle, each contract within the network could be governed by the law of contract; and, again in principle, the parties to each contract might be guided by the legal norms of that particular contract. However, the lack of fit between classical contract law principles and the connected configuration of networks suggests that, in practice, this is highly unlikely. One of the key issues concerns third-party liability within networks. This invites the question of which regulatory signals are operative in these networks. What really regulates the parties' dealings and holds the multiple contractual relations between the various parties in the network together? In addition, what does this signify for the law of contract? Can it be stretched to (help) govern the relationship within complex contractual networks or might tort liability be a better alternative?

Macneil cautioned against taking a particular contractual relationship (or transaction) out of the context of the larger web of social relationships within a network in which all agents are constrained by each other's actions. ${ }^{38}$ Ignoring this caution, traditional contract law often adopts a too narrow focus on the dealings between the individual parties. Yet, if we wish to understand the practice of contractors, we surely need to explore precisely those dimensions of the regulatory space that contract law so far treats as irrelevant. Financial transactions, which have been in the

37 See C. Joerges (ed), Franchising and the Law: Theoretical and Comparative Approaches in Law and Interdisciplinary Research (Oxford: Oxford University Press, 2014).

38 Generally, see Macneil (n 36). 
limelight since the economic and the Euro crisis, are currently at the forefront of new research initiatives. Here, the complexity of the contractual networks and, for example, the domino effects that may occur if the weak spots in the contractual interdependencies are ignored, have become visible. At the same time, the financial crisis has taught us that contractual networks suffer from the 'needle-in-the-haystack-problem'. To localise the weak spots and to identify who is responsible for what can be (made) immensely complex. Moreover, network governance is certainly not limited to financial transactions; supply chains in franchising, construction industry contracts and health care networks all seem to struggle with similar problems with one common denominator: traditional contract law falls short as a framework to govern the relationships within these networks. Therefore, we need to analyse first why this is the case, what the problems are, and whether the paradigms on which multi-party contracts rest need to be adjusted.

\subsection{Compliance}

In the field of public regulation there is an expectation that the processes and strategies employed by inspectorates and the like in order to secure compliance will meet standards of transparency, due process, and integrity. ${ }^{39}$ Deals done behind closed doors, veiled threats, the absence of an opportunity for a fair hearing, and so on, will arouse concern and provoke criticism. When we turn to compliance in the field of private transactions, concerns of this kind persist.

In principle, in the regulatory space for transactions, we might expect to find some signals that demand compliance by transactors (for example, by suppliers into the consumer marketplace) and others that are simply available for the use of (or at the option of) transactors. However, in some contexts, what looks like an option from a top-down perspective might (possibly via a 'nudge' or simply as a result of an imbalance of power) seem more mandatory. Just think of public laws that require private certification as evidence of compliance with regulations in the field of shipping or aviation (e.g. inspection of safety regulations). If refusing to get a (safety) certificate means that one will be subject to more frequent governmental inspections, or that one will be operating without insurance, one may wonder how 'voluntary' participating in private compliance actually is. For those who are subject to compliance monitoring it will probably make little difference who carries out the

39 See Karen Yeung, Securing Compliance (Oxford: Hart, 2004). 
'inspections'. The other way around, it may sometimes make little difference whether compliance monitoring and enforcement are carried out by public inspectors or private compliance officers if the public supervision is relatively easy to ignore or circumvent in practice. In other words, the significance of incentives to comply via monitoring and inspection will vary from one standpoint to another and they will vary according to the fields in which they are investigated.

The following areas could easily be identified where compliance is discussed, although the enumeration is not meant to be exhaustive: the use of contracts to ensure compliance with human rights and fundamental rights, and in supply chains upwards and downwards in the field of food production, textiles, and electronic devices. ${ }^{40}$ Another prominent field of compliance research deals with technical standards, certification and accreditation. Compliance with technical standards opens up markets; there is an incentive for companies to ensure that so-called technical requirements are met, not only in the field of production of technical goods, but also in the field of financial services. New modes of contracting are used to ensure compliance. Courts are gradually getting into the field and have to face all sorts of doctrinal questions. ${ }^{41}$

Private compliance management also raises important questions about enforcement. Who monitors transactional conduct and corrects for noncompliance (public or private?) as well as how are contracts enforced?42 Moreover, what is the influence of contractual compliance monitoring and payment for this by the norm addressees on the quality of the inspections? In the case of the PIP breast implants disaster, we have, for instance, seen that private auditing of the quality of the implants did not prevent the manufacturer from putting industrial silicone into the implants with major health risks as a consequence. ${ }^{43}$ Nor, we might add,

40 F. Cafaggi, 'The Regulatory Functions of Transnational Commercial Contracts: New Architectures' (2013) 36 Fordham International Law Journal 1558 .

41 R. van Gestel and H.-W. Micklitz, 'European Integration through Standardisation: How Judicial Review is Breaking down the Club House of Private Standardisation Bodies' (2013) 50 Common Market Law Review $145-182$.

42 Generally, see Brownsword, Micklitz, Niglia, and Weatherill (n 30) part four.

Special issue on PIP, RIDE 2015 volume 1, inter alia Hans-W. Micklitz, Norbert Reich and Lena Boucon, 'L'Action de la victime contre l'assureur du producteur' RIDE 2015, 37-68. 
did two audits by Primark prevent the collapse of the Rana Plaza building in Bangladesh. ${ }^{44}$

Even more radical is the question: what is the difference between compliance and enforcement, and how do they interact? Is compliance just a means to secure respect for the basic legal standards ex ante, whereas enforcement operates ex post, once the injury or the damage has occurred or is this distinction flawed in practice? ${ }^{45}$ Just think of the threat of collective action by NGOs via private law courts to make companies comply with environmental regulations. Undoubtedly, the possible consequences of collective action may cast a shadow over the compliance behaviour of private companies and on the willingness of public inspectors to monitor and enforce compliance with public regulations. The relationship between compliance and modes of enforcement plays a varying role in the different fields of research but the role and function can only be identified by taking a case-by-case approach, which after a while might allow for some general lessons to be drawn with regard to the effectiveness and legitimacy of various private compliance mechanisms in different circumstances.

\section{OUTLINE}

This Research Handbook compromises nine contributions, three on each of the principal focal topics - that is to say, three chapters on codes (by Marie-Claire Menting, Anna Beckers, and Mislav Mataija), three on networks and relations (by Rónán Condon, Catherine Mitchell, and Eric Tjong Tjin Tai), and three on compliance (by Monika Namysłowska, Paul Verbruggen, and Dorota Leczykiewicz). In this part of our introduction, we outline the content of these contributions.

44 See Andreas Rühmkorf, Corporate Social Responsibility, Private Law and Global Supply Chains (Cheltenham: Edward Elgar Publishing, 2015) at 215.

45 Christopher Hodges, Law and Corporate Behaviour: Integrating Theories of Regulation, Enforcement, Compliance and Ethics (Oxford: Hart, 2015); Hans-W. Micklitz and Andrea Wechsler, The Transformation of Enforcement in Europe (Oxford: Hart, 2016). 


\subsection{Codes}

In her contribution, Marie-Claire Menting focuses on industry codes. These codes refer to codes of conduct drawn up by industry organisations, either in collaboration with other actors (e.g. NGOs) or otherwise. Substantively, Menting concentrates on industry codes that set rules of conduct for or cover subject matters related to B2B or B2C contractual relationships that the addressees of a code of conduct engage in. Within these confines, her contribution seeks to gain insight into the implications of the rise of industry codes of conduct in the contractual regulatory space. Do we need a (legal) framework for industry codes with regulatory functions in contract law or could we leave the further development of the self-regulatory capacity of business and NGOs, with courts serving as a safety net?

Content-wise, Menting discerns between two different, yet not mutually exclusive, ways in which the B2B/B2C industry codes relate to their regulatory addressees (e.g. firms, NGOs, consumers). First, there are codes that set rules for the way in which a service is to be provided or a good is to be offered and sold. Secondly, codes can impose general rules of conduct or rules that concern the conduct of the addressees vis-à-vis third parties, such as competitors and consumers. Especially with regard to the second category, there may be a difference between codes that provide rights to third parties and codes that impose obligations on these parties. As to the way in which codes generate binding effect, this could make a difference. In her case law analysis, Menting shows that industry codes can be applied, first, in the context of open-ended standards in the law of contract. Secondly, codes can gain legal relevance by fitting them into the legal jacket of contract law concepts, for example via the concept of third-party beneficiary clauses. Thirdly, she shows that codes can be relied upon in a direct fashion by referring to them as self-standing arguments.

This last category, especially, is interesting because so far legislatures and courts have served as the gatekeepers to the legal system. Even in the case of customary private law, courts were often called upon to determine whether a certain custom had grown into customary law. Could it be, though, that codes of conduct develop into an independent third source of law, next to statutes and judicial precedents? Menting seems to believe that this is possible, in particular where both the drafter of the code and the addressees believe it should rule their relationship. Where, however, there is no contractual or organisational commitment, the question of binding force is turned into one of the third-party effects and privity of contract, which usually provides an obstacle to binding force. Yet she 
sees ways to circumvent these obstacles. Besides using a perpetual clause there can be a radiating effect of the code, effectuated via open-ended contract law standards. The argument could be that the code bears such importance for a significant part of the industry that non-subscribing industry actors are also bound by the code rules. However, owing to the far-reaching consequences of this route, it will probably be used only in exceptional cases.

The objective underlying Anna Beckers' contribution is to deliver insights into the character of (individual) corporate (CSR) codes, which she defines as unilateral self-commitments by companies to respect fundamental societal interests such as human rights, labour standards, or environmental protection. She argues that this new form of private regulation challenges different aspects of traditional contract law. More concretely, contract law is called upon to specify the duties of private regulators and substantive rules for their interaction with public law with the objective of corporations regulating themselves as private regulators and codes of conduct as the means of regulation. Beckers analyses the reasons behind this, such as the lack of power of national legislatures to regulate corporate behaviour in a transnational context and the simultaneously growing demand by shareholders, NGOs, and civil society more generally that companies respect fundamental rights and behave in a responsible manner towards workers, consumers, and local communities.

Just like Menting, Beckers argues that as unilateral acts corporate codes conflict with the underlying principle that enforceable obligations need to be reciprocal, which renders it difficult for contract law to determine whether these codes become legal obligations. In the strategic reliance on contracts and contract law enforcement through incorporation into contracts, questions arise as to the principles underlying the interpretation of these contracts between the intention expressed in the contract, the legitimate expectations of the addressees, and the principle of contractual fairness as expressed in principles of fair dealing and good faith.

According to Beckers, the inherent conflict in contract law relates to the question of the extent to which contract rules that are envisaged to cover the negotiation and enforcement of private contracts between two contractors can be used for constellations where companies effectively agree to regulate the public sphere through codes of conduct. Or, concretely, whether the limited and exceptionally applied rules on the third-party effects of contracts under the rules of contract formation and enforcement can accommodate the participation and accountability of regulated collectives. Beckers seems to consider it inevitable that contract 
law itself needs to change and become more 'regulatory'. She believes that contract law should help to enforce corporate codes as legal obligations on the part of the corporate entity through contextual contract interpretation and the acceptance of a unilateral declaration as a source of legal obligations. For this purpose, the duties of private parties and the remedies for breach of contract would need to be procedurally and substantively informed by public law frameworks, and third-party rights would require to be more extensively used for these types of contract.

Even though this might pose serious challenges for the traditional values and characteristics of contract law, Beckers seems to feel that there is no escaping the need for contract law to change because preserving the integrity of the system of contract law is not something that can be viewed in splendid isolation. It is crucial to safeguard the social function that contract law fulfils, namely to stabilise social expectations by applying general pre-developed and predictable norms to actual cases and maintaining the unity in the system within a changing (global) social legal order. In order to preserve trust in the self-regulatory capacity of business, one simply needs enforcement mechanisms to ensure compliance with CSR codes. This is not only a matter of effectiveness of private regulation but also a matter of legitimacy.

That contract law is already changing under the influence of EU internal market law is shown by Mislav Mataija. Completely in line with Menting and Beckers, Mataija concludes that codes of conduct pose a challenge to formalist doctrines of contract law, built on assumptions such as freedom of contract and private autonomy. Codes of conduct may, for instance, be used to reinterpret the obligations of contractual parties in a way that corresponds with the standards set by the particular community of traders, as expressed in a code of conduct. This may be the case whether or not the terms of a code are expressly incorporated into the contract and whether or not the contracting parties were involved in the adoption of the code. However, Mataija also reveals the way in which contract law can incorporate and refer to codes of conduct, for example in order to define what constitutes unfair commercial practices in the sense of Directive 2005/29/EC. Even where there might be a conflict between a code of conduct and the requirements of contract law, EU internal market law could moderate that conflict.

Mataija gives the example of an attorney who is suing a client for outstanding legal fees. The client invokes a competition law defence by claiming that the fee is illegal because it was the result of a cartel between attorneys that violated free movement and competition rules. In such a case Mataija believes that the judges who decide the case will need to look beyond the confines of the contract between the attorney 
and his client to see whether the prices were illegally fixed. Here the judge could not only look at the economic context of the market for legal services, but might also include the various rules governing the legal profession, including codes of conduct. Hence, codes of conduct could be used to fill in gaps in existing legislation or case law via the rules of EU internal market law.

What emerges from the examples given by Mataija is that EU internal market law could play a moderating role in the relationship between contract law and codes of conduct. On the one hand, internal market rules and competition law could mitigate undesirable consequences of unlimited self-regulation. An anticompetitive agreement or unjustified restriction of free movement rules expressed in codes of conduct should not be permitted to excuse practices claimed to be unfair. On the other hand, codes of conduct can equally help to interpret contracts, to determine what constitute unfair terms or to explain the rights of third parties to a contract. Mataija shows that EU internal market law has some potential as a control mechanism to monitor industry self-regulation via codes of conduct but the scrutiny usually does not go very deep. Therefore, as Menting and Beckers have argued, a more fundamental rethinking of contract law doctrines and concepts will be necessary in the near future to facilitate the use of codes of conduct within (European) regulatory private law.

\subsection{Networks and Relations}

Characteristically, the classical law of contract isolates a discrete transaction (typically, for the sale of goods or the supply of services) together with the immediate parties to that transaction (such as the supplier and the purchaser). While such isolation and discreteness, filtering out the background 'noise', facilitates placing a contractual dispute between the parties in a narrow and focused context, it treats as irrelevant a number of considerations that might be thought to be relevant to an adequate resolution of the questions raised by the parties. For example, the classical law approach excludes consideration of the connectedness of the transaction or its place within a cluster of contracts; it excludes consideration of the many social relationships - relationships within a family, with friends and neighbours, at work and in business circles, and so on in which the parties find themselves and which form the background to the transaction; and it excludes consideration of whether the parties are dealing on a level playing field. To some extent, the modern law has corrected for the last-mentioned shortcoming by recognising that contracts between business suppliers and consumers should be regulated in a 
different way from transactions made between business people. Moreover, where the law is sensitised to the de facto assumptions on which people contract - whether these assumptions are grounded in usual custom and practice, marketplace norms, or the signals given by a co-contractor - there is an opening for an approach that broadens the context for the dispute. However, once some of the background noise is admitted as relevant, the question is where the limits of the context are then to be found.

In recent years the English law of contract has reworked its classical approach by adopting as its guiding principle the idea that the law should be applied in ways that protect the reasonable expectations of honest contractors. ${ }^{46}$ This idea, as Rónán Condon explains in his chapter, is capable of giving the courts a broader view of the parties' relationship strikingly, for example, in the interpretation of commercial documents the courts have been able to refer not to the Organisation for Economic Co-operation and Development, but to the understanding that reasonable business people, in the shoes of the parties (and in their marketplace), would have of the contested provisions; and, in the same way, the test of the parties' particular rights and obligations is to be found not so much in the classical rule book, or in the express terms of the agreement, but in the parties' reasonable understanding of what the ground rules are for transactions in their particular relationship or in their particular marketplace.

While this might seem to be some improvement on rigid classical thinking, Condon argues that it is a mistake to continue to view the parties' reasonable transactional expectations exclusively through a contractual lens. Granted, a dispute that arises from a transaction will most naturally engage the law of contract; but the parties enter into the transaction and perform against a background of basic community obligations - that is to say, when the transacting parties are related to one another as members of the same community, they already share certain standards of interactional reasonableness as well as inter-personal fairness and good conscience. Some of these ideas will be reflected in the applicable law of contract (for example, where the law requires parties to act in accordance with the principle of good faith and fair dealing) but some of the ideas will give shape and substance to particular laws of tort or to equitable principles. Given that the contracting parties' reasonable

46 Notably, see Johan Steyn, 'Contract Law: Fulfilling the Reasonable Expectations of Honest Men' (1997) 113 LQR 433; and John N. Adams and Roger Brownsword, Key Issues in Contract (London: Butterworths, 1995). 
expectations will be coloured before, during, and after any particular transaction by these background standards, Condon contends that we cannot coherently claim to be trying to protect the parties' reasonable expectations and yet simply exclude these background standards - in other words, we cannot coherently treat the particular transaction as automatically displacing these standards of reasonableness and equity.

Where a claimant in English law seeks to pursue claims concurrently in contract and in tort, this presents some complex questions about how the 'interfaces' between different sections of the law are to be managed. Generally, there is a concern that claimants might try to bypass contractual restrictions by pleading the point in tort, or that attempts might be made to bypass restrictions in tort (notably concerning attempts to recover purely economic losses) by pleading the point in contract. However, where this is not a concern, there is a willingness to allow the claimant to take advantage of the more favourable body of law. Faced with this jurisprudence, Condon argues that we should reframe the interface issues as ones concerning the parties' reasonable expectations. To be sure, there might be many cases in which it is clear that the only reasonable understanding is that disputes arising out of the transaction are to be settled by reference to the foreground contractual standards; but, there will be others where the protection of reasonable expectations requires the application of the background standards. So stated, the challenge for modern law goes beyond ranking and ordering the various reference points for claimed reasonable expectations viewed through a contractual lens to some kind of meta-regulatory ordering of the signals and standards that transacting parties find in both their foreground and background relations.

Turning to the questions raised by connected contracts, particularly by those contracts that form a so-called 'network', Catherine Mitchell begins by remarking on the protean forms of contractual connection and networking. However, from the various articulations of networks, it is possible to highlight a number of features of such transactional phenomena that make them a poor fit relative to the classical law of contract. First, each contract that makes up the network contributes to the overarching interests or purposes that bring parties into the network. To extract a particular contract from its network background is to misstate its commercial purpose; and to detach the parties to a particular contract from the connections that they have with other members of the network is to present their relationship in a misleading way. Secondly, to restrict a network contractor's reasonable expectations to the terms of a particular contract is to understate, even to exclude, the expectations that a contractor might reasonably have by virtue of being a member of a 
network. Thirdly, to use Mitchell's own words, 'networks are usually a response to particular social conditions and project constraints on the part of economic actors, the result of which is a desire to create cooperative relationships with other firms in the interests of efficiency, and where the pursuit of self-interest is attenuated'. To the extent that the classical law of contract operates with a strong default for self-interested dealing, it is likely to be very slow to respond to a culture of cooperation (unless it is unequivocally embedded in the express provisions of the particular contract at issue).

Given this lack of fit, one might wonder whether the law of contract has any useful role to play in contributing to the regulation of network dealings. However, in the event of disputes between members of the network (particularly where one member claims that another has fallen short relative to reasonable expectations of cooperation, or where the question lies in a grey area between competition and cooperation), litigants might fall back on the law of contract. If, in such an eventuality, the courts simply reverted to the default of the classical law, this would endorse self-interested dealing that might be quite at odds with the implicit norms of the network. Rather, if the law of contract is to facilitate commerce by enabling parties to deal with trust and confidence in one another, it needs to respond to network disputes in a way that is more sensitive to the balance of self-interest and cooperation that is reasonably expected in such relationships. Among other things, Mitchell (highlighting the contrasting judicial opinions in the Jet2.com case) ${ }^{47}$ argues, this entails adopting a more sympathetic approach to the sometimes uncertain and imprecise terms in which a network's cooperative expectations are expressed as well as adopting an interpretive approach that takes into account the full range of aspirational norms that are in play.

Mitchell concludes that, while 'it is unlikely [that] English contract law will develop special rules to deal with networks', there is reason to think that - particularly by building on the modern contextual approach to the interpretation of commercial paper - it could rise to the challenge, reading the rights and obligations expressed by each contract within a network relative to the spirit of common purpose and cooperation that defines that network. No doubt this will not always be an easy task; but, then, the network cases that are (occasionally) brought to the courts are likely to be hard ones anyway, where the self-regulated norms offer no clear answer.

47 Jet2.com Ltd v Blackpool Airport Ltd [2012] EWCA Civ 417. 
Problems arising from multiple relations and networks are not unique to English law. In his contribution, Eric Tjong Tjin Tai explains how Dutch contract law, with its more contextual approach, is able to respond to many of the questions that are problematic relative to more formalist and inflexible regimes of contract law. For example, a contextualist approach to interpretation of contracts facilitates taking into account the informalities and implicit expectations of networks; a more fluid understanding of the relationship between contractual and tortious duties 'allows for a seamless framework for distributing obligations and assigning liability to network expectations'; a more flexible approach to third-party claims again allows for the context to be given due consideration; and the effects of remedies are tailored to the context in which they are invoked.

Having sketched the considerable capacity of Dutch contract law to take both a broader and a deeper view of the context in which a dispute is located, the question is whether there might be further applications of contract law that would facilitate the purposes of parties to networks. In order to focus this part of the chapter, Tjong Tjin Tai introduces three test cases, the first concerning safety-related communication in construction, the second concerning data sharing (about diseases, patients, and so on) within health care networks, and the third concerning profit sharing within innovation networks. In the first two cases there is a risk that the network aspiration for intelligent information sharing might be hampered by a contract law intervention that formalises the duty to inform and that focuses on outcomes rather than processes - in either case detrimentally affecting the complexion of the regulatory environment. ${ }^{48}$ In the third case, we have a more familiar problem as more powerful members of the network, having got what they want from the initial acts of cooperation, now seek to impose less cooperative arrangements. In all cases 'smart' responses are needed, possibly drawing on a suitably designed version of contract law but always sensitive to the way in which a particular regulatory intervention will operate in a regulatory environment that already includes a mix of legal rules and doctrines together with informal norms and standards.

In sum, just as 'smart regulation' in general cautions as to the limitations of particular regulatory instruments and advocates a sensitive

48 For the ways in which technological fixes can impact subtly, but negatively, on the complexion of the regulatory environment, see Roger Brownsword, 'Lost in Translation: Legality, Regulatory Margins, and Technological Management' (2011) 26 Berkeley Technology Law Journal 1321-1365. 
use of combinations of instruments, ${ }^{49}$ resort to contract law needs to be smart in recognising the limits of this body of law, in understanding that its use might be counter-productive, and in finding an effective orchestration of instruments.

\subsection{Compliance}

In the context of public regulation, 'compliance' represents one dimension of the regulatory enterprise. Regulators set standards for regulatees; they monitor for compliance and non-compliance; and, in the event of non-compliance, they take corrective action (sometimes relative only to individual regulatees, but at other times more generally by re-regulating). By contrast, in the context of private law transactions and in the event of non-compliance, the law of contract gives the innocent party the paper option of suing (or 'enforcing' the contract against) the contract breaker. Neither of these sketches, however, captures the interaction and hybridity that we often find in practice between public and private regulatory roles.

In her contribution, Monika Namysłowska highlights the role played by compliance officers, who are based in the private sector but who assist in securing compliance with public regulatory objectives. Sometimes compliance officers have general responsibilities but at other times they are specialists with a responsibility for a particular matter, such as respect for data protection law or for competition and merger law. Sometimes the initiative for appointing compliance officers comes from the private undertaking itself; but at other times (especially in some areas of EU law), the process is initiated by public regulators (as when, in competition matters, the Commission appoints monitoring trustees). Although compliance is now an industry, the appointment of compliance officers does not, of course, guarantee that a firm's culture will be fully geared for compliance. Ticking boxes is one thing; running a profitable business is something else. Namysłowska concludes that these developments raise questions about how 'to strike the proper balance between the public and private interest as well as between the private and public law'.

Highlighting a rather different kind of interaction, Paul Verbruggen focuses on the compliance strategies found in extended global supply chains. As Verbruggen explains, for a variety of reasons - such as the global nature of the business, the lack of effective intergovernmental rules, the risk of liability together with the risk of reputational damage,

49 See Neil Gunningham and Peter Grabosky, Smart Regulation (Oxford: Oxford University Press, 1998). 
and the expectations of consumers (who prefer to buy both with confidence and with a clear conscience) - there has been a growing use of private governance by large retailers and brand-name companies. Such governance can assume more than one form but, paradigmatically, privately adopted standards are embedded in supply chain contracts. Sometimes, suppliers are vetted for compliance with the relevant standards before they are admitted into the chain; and then there are provisions for inspection, audit, certification, and the like (the focus for which, as Verbruggen notes, is often on process rather than product).

While this all looks fine on paper - indeed, it seems that such private governance and its mechanisms serve to complement and reinforce public regulation of health and safety, the environment, and so on - it hardly needs saying that business logic is driven by the promotion of private rather than public interest. The business case for adopting codes of corporate social responsibility, for insisting on compliance, for securing compliance through inspection and audit, and so on is driven by a distinctive economic rationality. Even the judgement that non-compliance should be taken to a court needs the backing of a business case; and, as Verbruggen points out, it should not be forgotten that the 'absence of a credible threat of state-supported enforcement may seriously compromise the regulatory potential of non-state, private means'.

Where compliance with codes is channelled through the courts there are challenges for a law of contract that is geared for carefully defined obligations rather than loosely expressed provisions that are designed for flexibility - a challenge that Verbruggen (echoing Mitchell) believes can be addressed by a contextual style of interpretation. There is also the familiar challenge of doing justice to the reasonable expectations of third parties. Within the supply chains there are ways of enabling 'leapfrogging' (A leapfrogging $B$ to sue third party $\mathrm{C}$ ); but the more serious challenge is to do justice to the interests of employees and consumers and the like (as highlighted by the well-known Wal-Mart case). If, notwithstanding the intentions of the contracting parties, these supply chain contracts are to become a vehicle for the enforcement of minimum labour standards, minimum standards of health and safety, and so on, then the law of contract is being pressed into a quite different kind of regulatory service. While the precise meaning of 'regulatory private law' might be a matter for continuing debate, if the law of contract were to be used in this way to secure compliance with the publicly supported purposes, this would seem to be an illustration of this phenomenon.

Dorota Leczykiewicz stands back from this phenomenon to consider what we might gain by viewing contracts as having regulatory effects and contractual performance as a case of regulatory compliance. At first 
blush, this might seem a somewhat unpromising approach because, while regulatory theory has often focused on 'what works' (which interventions with which instruments are effective), contract theory tends to focus on the conditions under which transactions may be legitimately enforced. But, then, perhaps, regulatory theory should take questions of legitimacy more seriously and contract theory should take more interest in questions of effectiveness.

At all events, Leczykiewicz concentrates on three particular examples of private contracting that have regulatory effects, namely the use of standard terms, collective agreements, and vertical distribution agreements. As is well known, the one-sided imposition of standard terms (on a take-it-or-leave-it basis) has negative regulatory effects for those contractors, especially consumers, who have no real choice other than to deal on those terms. To some extent, courts might resist enforcement of such terms by appealing to the general conditions under which contracts may be enforced; but there is also the possibility of viewing these trading practices as presenting unacceptable risks to consumers who need public regulatory protection. In the case of collective agreements, the fact that a number of parties sign up to a set of provisions is, at least prima facie, a good reason for holding them (the parties), as well as those whom they might represent, to the agreement. However, as Leczykiewicz points out, there remain questions about exactly who is bound by the agreement (where there are negative regulatory effects for particular individuals) and, very importantly, there might be questions about the compatibility of the terms of the agreement with the community's background values (such as, in the EU, the treaty commitments to the fundamental freedoms). Somewhat similarly, the fact that vertical distribution agreements are backed by the consent of the parties involved does not exclude cross-checking (by judicial review) the terms of the agreement against the public interest or community values.

Accordingly, if we accept Leczykiewicz's invitation to view contracts through a regulatory lens, we should perhaps start with public regulation as our backcloth (let us assume for the sake of the argument that there is still such a clear distinction between public and private regulation). As a matter of public regulation, some space is reserved for private governance; and the law of contract, underpinned by the values of autonomy and freedom of contract, operates in this space. However, private governance is legitimate only to the extent that it has a social licence that authorises its use. The terms of that licence might be such as to restrict some manifestations of private governance or to require certain processual criteria to be satisfied. Once we start thinking along these lines, contracts are very much on the regulatory radar and the law of contract is 
not free-standing but just one piece in a larger regulatory environment that seeks to accommodate the perennial tension between individual right and collective good.

\section{CONCLUSION}

This Research Handbook does not offer a clear and comprehensive map of the shifting regulatory landscape of which the law of contract and transactions are a part. However, it does prompt further questions about our engagement with that landscape - particularly so if we think of the law of contract (along with other sections of private law) as an instrument to be used in a purposeful way. What we are contemplating then is a regulatory toolbox that offers regulators a range of instruments that can be used individually or in combination to bring about some desired state of affairs; and we might see some advantage in this whether our interest is in describing and explaining the state of contract law today or, indeed, in finding more effective ways of realising legitimate regulatory purposes.

How might we then view the 'hybrid' regulatory arrangements that we have found somewhat puzzling? Andreas Rühmkorf answers in the following terms:

Within [a] ... hybrid regulatory system, the various areas of private law ... serve different functions at different levels. First, company law and corporate governance, within the framework of the enlightened shareholder value theory, set the foundation for the company's CSR engagement through directors' duties and expectations in disclosure rules. Secondly, through contract law, private law provides a mechanism for companies to incorporate and to enforce CSR commitments ... Thirdly, private law provides a further tool of enforcement for consumers. They can ensure that companies comply with their publicly adopted CSR commitments. Fourthly, tort law contributes to this regulatory system by imposing civil liability for conduct of companies that violates CSR principles. ${ }^{50}$

Of course, this particular mix might not be the most effective - and it hardly needs to be emphasised that there are some formidable obstacles in the way of individuals who are cast in the role of enforcers against corporate defendants who have not fully internalised their declared CSR commitments. Nevertheless, the idea that, if only we thought about it in

\footnotetext{
50 Rühmkorf (n 44) at 207.
} 
this way, private law in general, and the law of contract in particular, might be of more general regulatory utility merits serious consideration.

In this light, what should we make of the particular topics on which this Handbook focuses? Perhaps a regulatory approach to networks and relations has the least radical implications. If it is thought to be desirable to support networks and to sustain the cooperative relationships that are characteristic of these arrangements, then in many legal systems the resources are available to do that. To be sure, in those legal systems that adhere to a classical model of the law of contract, the fact of the matter is that the law will not be responsive unless it makes some adjustment to, inter alia, its underlying individualist ethic, its demand for complete certainty of terms, and its restrictive third-party rules. Yet, where such systems reposition themselves by explaining their purpose by reference to the reasonable expectations of the parties, this seems no more than a small step to take. Once contract law is seen as an instrument that can be adjusted to fit the particular requirements, it can be rendered fit for purpose. That said, the challenge for such a revitalised and responsive law of contract is to know when importing enforceable contractual relations will interfere with other, more effective, mechanisms for achieving the desired purposes.

Our discussion of codes and compliance, on the other hand, suggests more radical implications for the law of contract. At minimum, global trade needs to be compatible with cosmopolitan values such as respect for human rights and human dignity;51 and, while regulators are unlikely to view the law of contract or any other part of private law as the instrument of choice in promoting respect for these values, they might have a part to play. If 'top-down' public regulation is necessary but not sufficient, perhaps some 'bottom-up' regulation by the trading community will complement and reinforce such efforts. However, there needs to be an appreciation of how far traders can be co-opted into the project given the imperatives that drive their business and shape their willingness to cooperate. Introducing into this arena a more flexible law of contract might push business beyond its limits and prove to be counter-productive. Simply because regulators realise that the law of contract is an instrument that might be deployed, it does not follow that deploying it is always the

51 See Roger Brownsword, Rights, Regulation and the Technological Revolution (Oxford: Oxford University Press, 2008) ch 7, and 'Regulatory Cosmopolitanism: Clubs, Commons, and Questions of Coherence', TILT Working Papers No 18 (Tilburg, 2010). 
smart choice. Hybrid regulation might do better than aspirational declarations or attempts at command and control; but, as in any public/private partnership, there are likely to be compromises.

Finally, there is regulatory private law in Europe, where contract law is apparently being repurposed for macro-economic objectives. There is a great deal to be written about this - but not in this Research Handbook. Suffice it to say that, while classical contract law might be presented as having the objective of increasing welfare, this is some way short of macroeconomic management of the kind that we associate with fiscal and tax measures. Fine-tuning the regulatory environment by making some adjustment to the scope or substance of contract law is one thing; using the law of contract to steer the economy in a particular direction is surely something rather different. 
Roger Brownsword, Rob A. J. van Gestel, and Hans-W. Micklitz - 9781784710668 Downloaded from PubFactory at 04/26/2023 05:20:59AM 